\title{
Retrotransposon Cassandra copies estimating in plums using real-time PCR approach
}

\author{
Jana Žiarovská*, Danka Bošel'ová, Milan Bežo \\ Department of Genetics and Plant Breeding, Slovak University of Agriculture, Tr. A. Hlinku 2, 94976 Nitra, Slovak Republic
}

\section{A B S T R A C T}

\begin{abstract}
Gene or genome elements copy number is usually determined by the time consuming Southern blot analysis. In the study, a real-time PCR protocol approach was used for the estimation of retrotransposon Cassandra copies number. Performing real-time PCR analyse we have quantified number of copies of internal domain of Cassandra in twenty-three Prunus domestica, L. accessions in a range from 25122 copies (Prunus domestica, L from Lipany region) up to the 188389 (Lutzelsachsenska). A conserved 18S rRNA gene was used for standard curve construction and for the calculation of the amount of DNA containing its single copy. Here, the absolute quantitation was prooved as to be suitable for routine analysis of retroelements number copies in plants. It provides fast, inexpensive and high-throughput alternative to the other used methods.
\end{abstract}

Keywords: Retrotransposon Cassandra, Prunus domestica, L., Real-time PCR, Number of copies

\section{INTRODUCTION}

Retrotransposons are an inevitable part of the throughout all life domens and large plant genomes consist of $>50 \%$ of these elements. One of them, terminal repeat retrotransposon in miniature posses no reading frames for retrotransposon specific proteins. They consist from following: LTRs, reverse transcriptase priming site and an intervening segment. TRIMs are expected to be activated by transcomplementation (Kalendar et al. 2008). They are used widely in genome diversity studies for the purpose of the assessment of agricultural biodiversity on interspecific and intraspecific level (Žiarovská et al., 2012; Trebichalský et al., 2013; Balážová et al., 2014).

Cassandra as one of the TRIM elements, posses conserved $5 \mathrm{~S}$ rRNA sequences and in its LTR is a promoter for RNA polymerase III. Very similar as another members from this group, Cassandra is highlu copied throughout the higher plants (Kalendar et al. 2008). They are a dynamic component of the genome, affecting both gene expression and overall genome structure. Until very recently, the nonautonomous retrotransposons were considered the junk of the junk (Schulmann 2007). Retroelement parasites such as Cassandra have no coding capacity but appear to exploit not only proteins of other retrotransposons but also those of the cell. Furthermore, the plant cell must regulate the replicative capacity of the retrotransposon to prevent unlimited, disruptive integration of new daughter copies (Schulmann 2007). Cassandra elements have not autonomous transposition and as reported by many studies, they are dependend on the help of mobility-related proteins that are encoded by other retrotransposons (Witte et al. 2001).

Traditionally used methods for the determination of gene copies is Southern blot hybridization. In this approach, two possible counting strategies are reported. In the first method, single restriction site in the cassette is chosen to digest the gDNA, and this is used for Southern blot hybridization with specific probes. If a sinle band is obtained in Southern blot, the copy number should be one (Bubner and Baldwin 2004). In the second method, the same amount of gDNA from different assessions is digested using two restriction enzymes that cutt flanking regions to obtain a fragment of an expected size, that is subsequently hybridized with a specific probe (Yuan et al. 2008).

Alonso et al. (2004) reported that determinig of the template molecules number is desirable and can be

\footnotetext{
*Corresponding author:

Jana Žiarovská, Department of Genetics and Plant Breeding, Slovak University of Agriculture, Tr. A. Hlinku 2, 94976 Nitra, Slovak Republic. E-mail: jana.ziarovska@uniag.sk
} 
performed not only by high sensitive hybridization with specific DNA probes (Walsh et al. 1992) or by competitive PCR (Handt et al. 1996), but more recently, by using real-time quantitative PCR (Walker et al. 2003). Real-time PCR detects amplification products directly as they are produced. Subsequently, the Ct value is setting as the cycle at which fluorescence significantly exceeds the background (Higuchi et al. 1993). Ct value describes the state when product accumulation correlated with the amount of starting template. A lower Ct value describes a higher starting quantity of the template. Threshold is desirable to be achieved withing the exponential phase, where no limitation in the PCR exist and $\mathrm{Ct}$ values are reproducible (Higuchi et al. 1993). Optimizing this has the result of precision in DNA quantitation. Quantitation of the template in analysed accessions is performed by a standard curve approach or by using of internal controls approach (Gentle et al. 2001, Raeymaekers 2000, Song et al. 2002). Generating the standard curve results in linear plot of a set of standards initial copy number logs versus $\mathrm{Ct}$ value. Subsequently, Ct-s of analysed accessions is determined, and constructed standard curve is what determines their starting copy number (Higuchi et al. 1993, Song et al. 2002). Internal control approach works with an internal endogenous housekeeping gene that $i$ sused for normalization of the amount of template (Livak and Schmittgen 2001, Schmidt and Parrott 2001). Oantitation in this approach is based on the same efficiencies for the template and internal housekeeping genes ( $\mathrm{Li}$ et al. 2004).

In this study, a quantitative real-time PCR protocol was established for Cassandra retroelement analysis in the genome of Prunus domestica, L. Based on this protocol the Cassandra copies number was calculated using an absolute quantitation method. Finally, different plant accessions were compared for their Cassandra copies.

\section{MATERIAL AND METHODS}

\section{Genomic DNA extraction for real-time PCR}

Twenty-three plum (P. domestica, L.) genotypes were used in analysis. A detailed characteristic is listed in Table 1. Approximately $100 \mathrm{mg}$ of leaf tissue was ground to a fine powder in liquid nitrogen. Total genomic DNA was isolated using the isolation kit Invisorb Spin Plant Mini Kit (Invitek), according user's manual. The obtained DNA was quantified by fluorometer (Qubit ${ }^{\mathrm{TM}}$ ).

\section{Oligonucleotid primer design and real time PCR assays} Using data deposited in NCBI database about Cassandra retroelements in the plum genome (AY860314) were retrieved and used as template for designing real-time PCR oligos. 18S rRNA sequence for setting a standart curve was also obtained from NCBI database (FJ899098). Real-time PCR oligonucleotide primers were manually designed for both of them (Table 2) using internet-based interface of Primer 3 software.

\section{Real-time PCR assays}

Real-time PCR runs were performed in 96-well optical plates in triplicate, each containing 12.5 PCR master mix (SYBR Green BioRad), 0.2 pmol of forward and reverse primer $2 \mu \mathrm{l}$ template DNA (diluted to $20 \mathrm{ng} / \mu \mathrm{l}$ ), for 35 cycles using a BioRad CFX 96. Cycle conditions were as follows; 5 min at $95^{\circ} \mathrm{C}$ followed by 35 cycles of $10 \mathrm{~s}$ at $95^{\circ} \mathrm{C}, 10 \mathrm{sec}$ at $58^{\circ} \mathrm{C}$ and $30 \mathrm{sec}$ at $72^{\circ} \mathrm{C}$. A standard curve was drawn by plotting the natural $\log$ of the threshold cycle against the natural $\log$ of the number of molecules. The equation drawn from the graph was used to calculate the precise number of specific $18 \mathrm{~S}$ rRNA molecules.

\section{Verifying of amplification specifity by direct sequencing of Cassandra internal domain}

After the control of the PCR specifity by the melting point analysis of obtaining amplicons (that was set at $84.5^{\circ} \mathrm{C}$ ), cleaning step was performed for PCR products before the sequencing procedure. This was performed using Agencourt AMPure XP (Beckman Coulter) following the manufacturer's instructions. Sequencing PCRs were optimized for the molar ratio of $\sim 40: 1$ (primer to template) using the Dye Terminator Cycle Sequencing Genome $\mathrm{Lab}^{\mathrm{TM}}$ Kit (Beckman Coulter). Cycling was as follows: $96{ }^{\circ} \mathrm{C} 20 \mathrm{sec} ; 50{ }^{\circ} \mathrm{C}-20 \mathrm{sec}$ and final $60{ }^{\circ} \mathrm{C}-4$ minutes. Purification of sequencing PCR was performed by Agencourt ${ }^{\circledR}$ CleanSEQ ${ }^{\circledR}$ (Beckman Coulter) following the manufacturer's instructions. Sequencing of amplicons was performed in $\mathrm{CEQ}^{\mathrm{TM}-}$ Genetic Analyses System using the LFR-1 protocol. All the direct sequencing reactions were repeated twice.

\section{Data analysis using absolute qantification}

In order to compare samples, it was necessary to use appropriate form of calibration. The common method to employ a reference gene - $18 \mathrm{~S}$ rRNA was used. The quantity of Cassandra retrotransposon copies was interpolated from a range of standarts of known quantity. A 10-fold dilution series was created from a sample with a known concetration of $18 \mathrm{~S}$ rRNA gene, resulting in the set of standards containing up to the 112994 copies of the gene. The copy numbers were calculated based on the following formula, in which $n$ means the number of the base pairs, $m$ is the mass of the DNA, $N_{A}$ is the Avogadro's number $\left(6,02 \times 10^{23} \mathrm{bp} / \mathrm{mol}\right)$ and $M$ is the average molecular weight of a base pair. $\mathrm{n}=\left(\mathrm{m} \times \mathrm{N}_{\mathrm{A}}\right) / \mathrm{M} ; \mathrm{m}=\mathrm{n}$ $\times 1,096 \times 10^{-21} \mathrm{~g} / \mathrm{bp}$. The following equation to determine the quantity of an unknown sample was used $\mathrm{N}=10$ $((\mathrm{Ct}-\mathrm{b}) / \mathrm{m})$, where $\mathrm{Ct}$ is a threshold, $\mathrm{b}$ is the regression 
Table 1: List of analysed Prunus domestica, L. accessions

\begin{tabular}{|c|c|c|c|}
\hline No. & Genotype & Origin/Locality & Pedigree \\
\hline 1 & P. domestica, L. & Slovakia - Pečovská Nová Ves & Unknown \\
\hline 2 & P. domestica, L. & Slovakia - Torysa & Unknown \\
\hline 3 & P. domestica, L. & Slovakia - Podolínec & Unknown \\
\hline 4 & P. domestica, L. & Slovakia - Lipany & Unknown \\
\hline 5 & Gabrovská & Bulgaria & Kjustendilska×montfortska \\
\hline 6 & Chrudimská & Czech Republic & Accidental seedlings \\
\hline 7 & Švestka domácí & Czech Republic & Accidental seedlings \\
\hline 8 & Čačanská lepotice & Former Yugoslavia & Wangenheimovaxpožegača \\
\hline 9 & Anna spätch & Hungary & Accidental seedlings \\
\hline 10 & Čačanská ranná & Former Yugoslavia & Wangenheimovaxpožegača \\
\hline 11 & Čačanská rodná & Former Yugoslavia & Stanleyxpožegača \\
\hline 12 & Elena & Germany & Vlaškaxstanley \\
\hline 13 & Hamanova švestka & Czech Republic & Not specified \\
\hline 14 & Hanita & Germany & Presidentxauerbacher \\
\hline 15 & Katinka & Germany & Ortenauerxgerstetter \\
\hline 16 & Lutzelsachsenská & Germany & Accidental seedlings \\
\hline 17 & Presenta & Germany & Ortenauerxpresident \\
\hline 18 & Stanley & USA & Agenská $\times$ grand duke \\
\hline 19 & Tegera & Germany & Ortenauer×gerstetter \\
\hline 20 & Valjevka & Former Yugoslavia & Agenská $\times$ stanley \\
\hline 21 & Vlaška & Italy & Not specified \\
\hline 22 & Wangenheimova & Germany & Not specified \\
\hline 23 & Zimmerova & Germany & Accidental seedlings \\
\hline
\end{tabular}

Table 2: Real-time quantitative PCR primers

\begin{tabular}{llllc}
\hline Primer name & Primer & Sequence $\left(5^{\prime}-\mathbf{3}^{\prime}\right)$ & Concentration & Amplicon size \\
\hline PRUN18S-A-F & Forward & acgagagagcgcgtccccat & $400 \mathrm{nM}$ & $450 \mathrm{bp}$ \\
PRUN18S-A-R & Reverse & ggggtcgcgttgaaagccga & $400 \mathrm{nM}$ & \\
PRUN-ID-F & Forward & ccgtgagggcagagaggggg & $200 \mathrm{nM}$ & $364 \mathrm{bp}$ \\
PRUN-ID-R & Reverse & gctcccaaaaggctcgtgct & $200 \mathrm{nM}$ & \\
\hline
\end{tabular}

constant and $\mathrm{m}$ is the regression coefficient. Obtained quantity values where converted into the number of copies of both Cassandra retrotransposon and 18S rRNA by using the plum genome size of $323 \mathrm{Mbp}$ (Loureiro et al. 2007) and following formula for calculating the number of copies from quantifying DNA concentration: $\mathrm{m}=(\mathrm{n})$ $\left(1,096 \mathrm{e}^{-21} \mathrm{~g} / \mathrm{bp}\right)$, where $\mathrm{n}$ is a genome size in $\mathrm{bp}, \mathrm{m}$ is a mass and $\mathrm{e}^{-21}$ is equal to the $\mathrm{x} 10^{-21}$.

\section{RESULTS AND DISCUSSION}

Comparing the known sequences of Cassandra has shown the conserved regions among species. They were defined in the both of LTRs and in the part of the internal domain - in the primer binding site sequence. This sequence is considered to be conserved in Cassandra (Kalendar et al 2010), more, the authors based on the PBS sequence a new approach for Cassandra insertional polymorphism analyses - the iPBS method. Another study (Kalendar et al. 2008) has proved all of the known TRIM elements as containing a highly conserved region for $5 \mathrm{~S}$ RNA that corresponds to the LTRs. Using the first, or the second above mentioned approach, molecular DNA based analyses of Cassandra provide a wide range of germplasm evaluation.

Here, a real-time PCR approach is reported for a estimation of Cassandra retrotransposon copies in the genome of Prunus domestica, L., as both, genomic DNA and reverse transcribed cDNA can be used as templates for real-time PCR. Total genomic DNA of plum was used for estimation of TRIM retrotransposon copies when comparing it to the standart curve based on the $18 \mathrm{~S}$ rRNA gene.

Specifity of Cassandra amplification was inspected both, by melt analysis (data not shown) and by direct sequencing, too. Obtained sequences were BLASTed against the Cassandra sequence of Prunus domestica internal domain region previously registered in the NCBI database (AY860314). They were returned as identical (data not shown).

First, the real-time PCR protocol for the amplification of $18 \mathrm{~S}$ sRNA was optimized for futher analysis. 18S sRNA provided a good constitutive control as was shown by constitutive level of expression. After optimization of 
amplification conditions it was used as internal control for the subsequent experiments. Dissociation curves of 18S sRNA amplified products calculated by plotting the negative derivative of fluorescence emitted by the PCR sample during the melting procedure showed a single peak with $\mathrm{Tm}$ of $87.6^{\circ} \mathrm{C}$. This was identical for all analysed samples, indicating the specifity of PCR product (Fig. 1). Moreover, agarose gel electrophoresis of these products confirmed the amplification of a single fragment and no primer-dimer formation during the PCR (Fig. 2).

Control reactions did not generate any products with significant fluorescence. Cassandra retrotransposons are reported to be abundant and insertionally polymorphic (Cloix et al. 2000, Kalendar et al. 2008). Kalendar et al. (2008) found 6,697 \pm 588 copies of Cassandra element. In this study a probe using approach was chosen when the probe was constructed in a manner that it includes only a $5 \mathrm{~S}$ domain of Cassandra.

Analysis of the rice genome obtained 436 Cassandra 5S RNA sequences. A similar amount of $5 \mathrm{~S}$ genes, concretelly 384, were identified in rice (Cloix et al. 2000). Kalendar et al. (2008) also determine thousands of Cassandra in the ferns. These copies number corresponds to our findings in the hexaploid plum genome.

As the principle of absolute quantification is to determine the most exact copies of the target present in the template,

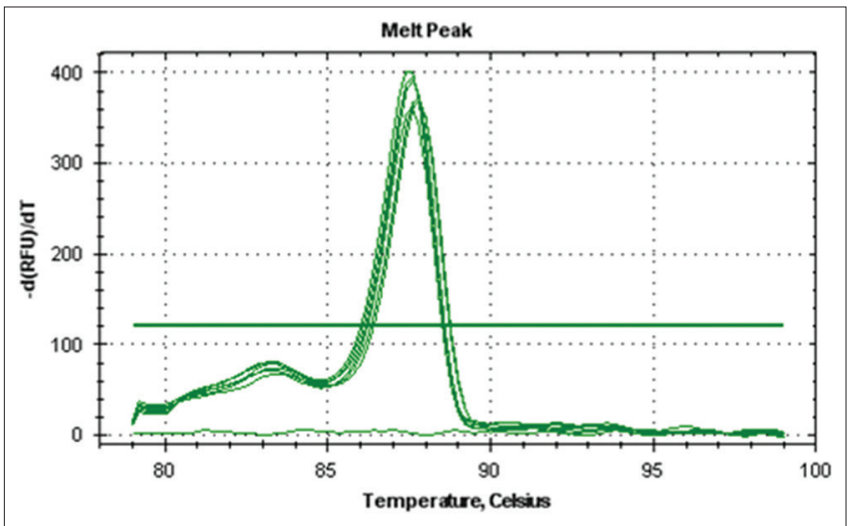

Fig 1. Melting analyses of $18 \mathrm{~S}$ rRNA PCR product of Anna Späch plum variety.

by relating the fluorescence signal to a standart curve, therefore requiring that the absolute quantities of the standart be known (Mackay 2004). This approach was used in a slightly modified version, where the quantity of Cassandra retroelement copies (Table 3) was interpolated from a range of $18 \mathrm{~S}$ rRNA standarts of known quantity in the hexaploid plum's genome. Beside the absolute quantification, the relative fold of amplification increase of Cassandra sequences was determined (Fig. 3) to comparing the calculated number copies with changes showed within the relative fold of Cassandra copies.

Similar method where the absolute quantification approach of standart curve construction was used for determining gene copies in transgenic mice (Yun et al. 2006). The authors reported that the quantification of gene targets such this provides a more effective form of data obtaining

Table 3: Number of Cassandra copies in individual Prunus domestica, L. accessions as estimated by real-time PCR approach

\begin{tabular}{lccc}
\hline Genotype & Ct & Quantity & $\begin{array}{c}\text { Number } \\
\text { of copies }\end{array}$ \\
\hline Prunus domestica, L. - Pečovská & 16,91 & 0,25 & 28448 \\
Nová Ves & & & \\
Prunus domestica, L. - Torysa & 16,62 & 0,30 & 34439 \\
Prunus domestica, L. - Pchorenec & 16,47 & 0,34 & 38287 \\
Prunus domestica, L. - Lipany & 17,1 & 0,22 & 25122 \\
Slivka gabrovská & 16,99 & 0,24 & 26981 \\
Slivka chrudimská & 16,12 & 0,43 & 48201 \\
Švestka domácí & 15,69 & 0,57 & 64129 \\
Čačanská lepotice & 16,78 & 0,28 & 31121 \\
Anna spätch & 16,57 & 0,32 & 35814 \\
Čačanská raná & 14,95 & 0,93 & 105452 \\
Čačanská rodná & 16,2 & 0,41 & 45820 \\
Elena & 15,5 & 0,64 & 72787 \\
Hamanova švestka & 15,27 & 0,75 & 84929 \\
Hanita & 16,75 & 0,28 & 31700 \\
Katinka & 15,17 & 0,80 & 90585 \\
Lutzelsachsenska & 14,08 & 1,67 & 188389 \\
Presenta & 15,27 & 0,75 & 85125 \\
Stanley & 15,38 & 0,70 & 79260 \\
Tegera & 14,62 & 1,16 & 130634 \\
Valjevka & 15,19 & 0,79 & 89548 \\
Vlaška & 15,37 & 0,70 & 79626 \\
Wangenheimova & 15,13 & 0,83 & 93337 \\
Zimmerova & 15,4 & 0,69 & 78173 \\
\hline
\end{tabular}

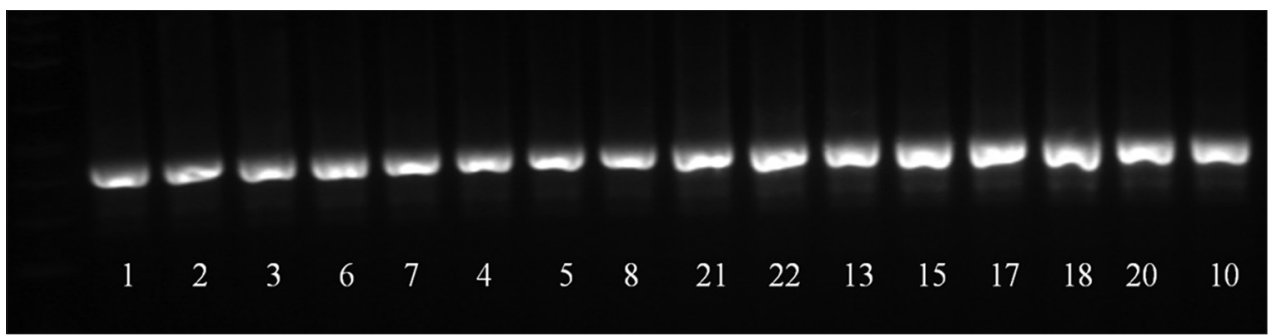

Fig 2. Electrophoreotic visualization of the specifity of $18 \mathrm{~S}$ rRNA PCR product amplification. Number of plum variety identification as in Table 1. 


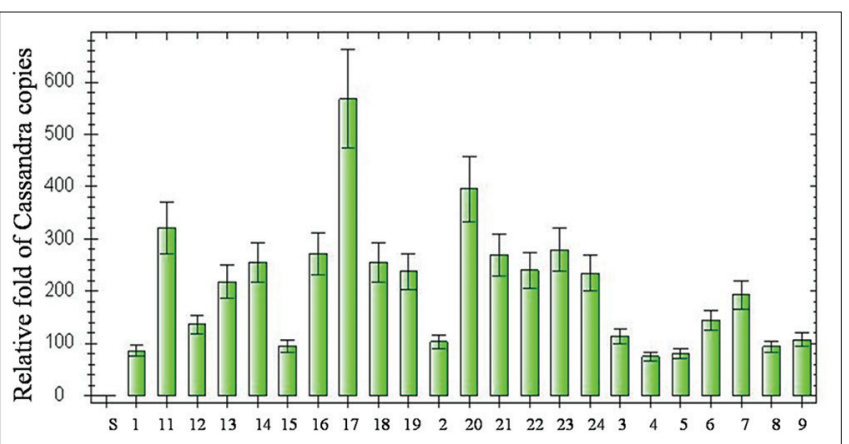

Fig 3. Visualization of SYBR detected real-time PCR based changes in Cassandra product amplification. Number of plum variety identification as in Table 1.

than relative quantification, but the universally accepted methodologies for achieving absulote quantification still not exist (Yun et al. 2006).

As the real-time PCR is sensitive and specific enough to distinguish a 1 - or 2-fold difference in target template, the counting of transgene copies in wheat was compared with results from Southern blot analysis (Li et al. 2004). Concordant results when comparing both of them were obtained for the nuclear DNA content for the most of analysed accessions $-70 \%$ of samples in the range of $>1000-30 \mathrm{pg}$ (Alonso et al. 2003). $30 \%$ of the analysed samples in the study of the same authors resulted negative for the blot analysis and positive when analyzed them by the real-time PCR. Authors have summarized this as strongly indicating that the real-time PCR is an efficient and more sensitive method than the blot hybridization. The concordance between real-time PCR and Southern blot results was approximately $90 \%$ (Li et al. 2004).

Cassandra elements as a fairly abundant family in plants genomes are reported in the case of rice (Kalendar et al. 2008). On the applied level, Cassandra elements have the potential to be a very useful molecular markers and the analysis of their functionality will aid exploitation in mapping and genome diversity studies. The portion of nonautonomous retroelements such as short nuclear interspersed elements and TRIMs in genomes of eukaryotics may be the result of a unique evolutionary relationship with their autonomous elements partners and the host genome, so the specific information about them are still required and the estimation of their number of copies is an inevitable part of them. Analyses of the rice genome provided by Pryer et al. 2001 resulted in that 15\% of Cassandra long terminal repeats and $21 \%$ of complete elements are the parts of the genes, but only $1 \%$ of them is in coding sequences. When compared, retrotransposon Tos 17 possess a similar distribution in the rice genome but about half the genic insertions are into exons. Unlike Cassandra, Tos17 is generally silent and rare, being found in one to five copies (Pryer et al. 2001).
Among the species in the Hordeum genus, BARE1 is present on an average in 14,000 copies, with 16,000 copies in barley (Vicient et al. 1999); the number varies across the genus. Based on these copy numbers and on the genome sizes, full-length $B A R E 1$ comprises $0.8 \%$ to $5.7 \%$ of the genome in genus, and this measure also varies across the genus Kankanpää et al. 1996). Vukich et al. (2009) reported, that sunflowers repeated sequences ot the three Gypsy-like sequences and one Copia - likesequence have a copy number per haploid genome ranging from 4,000 to 16,000 . Woloszynska et al. (2006) used real-time PCR in the verification of the differences in the copy numbers and steady-state transcript levels of mitochondrial genes coding for proteins or RNAs of four Phaseolus vulgaris lines.

Real-time PCR has provided the method of choice for not time consuming, relatively cheap, and effective estimation of copy number (Ingham et al. 2001, Mason et al. 2002, Bubner and Baldwin 2004). Various approaches have been tested to improve the effectivity of real-time PCR for this application using both the standard curve method and the $\Delta \mathrm{Ct}$ method involving an internal reference gene (Yang et al. 2005). Some details of several methods and their statistical models that were developed for these methods were discussed by Yuan et al. 2008 . Thus, the results presented in literature and obtained by this paper findings shown the strength of the real-time PCR approach in the genome elements copy number estimation.

\section{CONCLUSION}

In conclusion, it has been demonstrated the utility of realtime PCR for the quantification of genome transposable elements represented by the retrotransposon Cassandra. This methodology offers several advantages with respect to the hybridization methods, including: higher sensitivity, unnecessary post-PCR processing, the possibility to perform qualitative analysis of different aspects from different genomes, and the automation feasibility.

\section{ACKNOWLEDGMENTS}

This work was co-funded by European Community under project no 26220220180: Building Research Centre "AgroBioTech". Plant material was kindly provided by Výzkumný a šlechtitelský ústav ovocnářský Holovousy s.r.o., Czech Republic.

\section{Authors' contributions}

Jana Žiarovská performed real-time experimental procedures and statistical calculations, carried out drafting 
and writing the manuscript, and prepared the figures. Danka Bošel'ová performed nucleic acids extractions and helped with experimental procedures. Milan Bežo collaborated in data analysis and helped in drafting the manuscript. All authors were involved in revising the manuscript in progress and critically approving the final manuscript.

\section{REFERENCES}

Alonso, A., P. Martín, C. Albarrán, P. García, O. García, L. F. de Simón, J. García-Hirschfeld, M. Sancho, C. de La Rúa and J. Fernández-Piqueras. 2004. Real-time PCR designs to estimate nuclear and mitochondrial DNA copy number in forensic and ancient DNA studies. Forensic Sci. Int. 139: 141-149.

Balážová, Ž., A. Trebichalský, Z. Gálová, R. Kalendar, A. Schulman, O. Stratula and M. Chňapek. 2014. Genetic diversity of triticale cultivars based on microsatellite and retrotransposon-based markers. J. Microbiol. Biotechnol. Food Sci. 3: 58-60.

Bubner, B. and I. T. Baldwin. 2004. Use of real-time PCR for determining copy number and zygosity in transgenic plants. Plant. Cell. Rep. 23: 263-271.

Cloix, C., S. Tutois, O. Mathieu, C. Cuvillier, M. C. Espagnol, G. Picard and S. Tourmente. 2000. Analysis of 5S rDNA arrays in Arabidopsis thaliana: Physical mapping and chromosomespecific polymorphisms. Genome Res. 10: 679-690.

Gentle, A., F. Anastasopoulos and N. A. McBrien. 2001. High resolution semi-quantitative real-time PCR without the use of a standard curve. Biotechniques: 31: 502-508.

Handt, O., M. Krings, R. H. Ward and S. Pääbo. 1996. The retrieval of ancient human DNA sequences. Am. J. Hum. Gen. 59: 368-376.

Higuchi, R., C. Fockler, G. Dollinger and R. Watson. 1993. Kinetic PCR: Real-time monitoring of DNA amplification reactions. Nat. Biotechnol. 11: 1026-1030.

Ingham, D. J., S. Beer, S. Money and G. Hansen. 2001. Quantitative real-time PCR assay for determining transgene copy number in transformed plants. Biotechniques: 31: 132-140.

Kalendar, R., K. Antonius, P. Smýkal and A. H. Schulman. 2010. iPBS: A universal method for DNA finger printing and retrotransposon isolation. Theor. Appl. Genet. 21: 1419-1430.

Kalendar, R., J. Tanskanen, W. Chang, K. Antonius, H. Sela, O. Peleg and A. H. Schulman. 2008. Cassandra retrotransposons carry independently transcribed 5S RNA. Proc. Natl. Acad. Sci. 105: 5833-5838.

Kankanpää, J., A. H. Schulman and L. Mannonen. 1996. The genome sizes of Hordeum species show considerable variation. Gen. Biol. 39: 730-735.

Li, Z., J. L. Hansen, Y. Liu, R. S. Zemetra and P. H. Berger. 2004. Using real-time PCR to determine transgene copy number in wheat. Plant. Mol. Biol. Rep. 22: 179-188.

Livak, K. J. and T. D. Schmittgen. 2001. Analysis of relative gene expression data using realtime quantitative $\mathrm{PCR}$ and the $2^{\wedge \wedge} \mathrm{Ct}$ method. Methods: 25: 402-408.

Loureiro, J., E. Rodriguez, J. Doležel and C. Santos. 2007. Two new nuclear isolation buffers for plant DNA flow cytometry: A test with 37 species. Ann. Bot. 100: 875-888.

Mackay, I. M. 2004. Real-time PCR in the microbiology laboratory. Clin. Microbiol. Infect. 10: 190-212.
Mason, G., P. Provero, A. M. Vaira and G. P. Accotto. 2002. Estimating the number of integrations in transformed plants by quantitative real-time PCR. BMC Biotechnol. 2: 20. DOI:10.1186/1472-6750$2-20$

Pryer, K. M., H. Schneider, A. R. Smith, R. Cranfill, P. G. Wolf, J. S. Hunt and S. D. Sipes. 2001. Horsetails and ferns are a monophyletic group and the closest living relatives to seed plants. Nature: 409: 618-622.

Raeymaekers, L. 2000. Basic principles of quantitative PCR. Mol. Biotechnol. 15: 115-122.

Song, P., C. Q. Cai, M. Skokut, B. G. Kosegi and J. F. Petolino. 2002. Quantitative real-time PCR as a screening tool for estimating transgene copy number in WHISKERS ${ }^{\mathrm{TM}}$ derived transgenic maize. Plant. Cell. Rep. 20: 948-954.

Schmidt, M. A. and W. A. Parrott. 2001. Quantitative detection of transgenes in soybean [Glycine max (L.) Merrill] and peanut (Arachis hypogaea L.) by real-time polymerase chain reaction. Plant. Cell. Rep. 20: 422-428.

Schulman, A. H. 2007. Molecular markers to assess genetic diversity. Euphonium: 158: 313-321.

Vicient, C. M., R. Kalendar, K. Anamthawat-Jonsson and A. H. Schulman. 1999. Structure, functionality, and evolution of the BARE-1 retrotransposon of barley. Genetica 107: 53-63.

Trebichalský, A., R. Kalendar, A. Schulman, O. Stratula, Z. Gálová, Z. Balážová and M. Chňapek. 2013. Detection of genetic relationships among spring and winter triticale $(\times$ Triticosecale Witt.) and rye cultivars (Secale cereale L.) by using retrotransposon-based markers. Czech J. Genet. Plant Breed. 49: 171-174.

Vukich, M., T. Giordani, L. Natali and A. Cavallini. 2009. Copia and Gypsy retrotransposons activity in sunflower (Helianthus anuus L.). BMC Plant Biol. 19: 50. DOI: 10.1186/14-712229/9/150

Walker, J. A., G. E. Kilroy, J. Xing, J. Shewale, S. K. Sinha and M. A. Batzer. 2003. Human DNA quantitation using Alu element based polymerase chain reaction. Anal. Biochem. 135: 122-128.

Walsh, P. S., J. Varlaro and R. Reynolds. 1992. Arapid chemiluminiscent method for quantitation of human DNA. Nucleic Acid Res. 20: 5061-5065.

Witte, C. P., Q. H. Le, T. Bureau and A. Kumar. 2001. Terminal repeat retrotransposons in miniature (TRIM) are involved in restructuring plant genomes. Proc. Natl. Acad. Sci. 98: 13778-13713.

Woloszynska, M., B. Kmiec, P. Mackiewicz and H. Janska. 2006. Copy number of bean mitochondrial genes estimated by realtime PCR does not correlate with the number of gene loci and transcript levels. Plant Mol. Biol. 61: 1-12.

Yang, L., J. Ding, C. Zhang, J. Jia, H. Weng, W. Liu and D. Zhang. 2005. Estimating the copy number of transgenes in transformed rice by real-time quantitative PCR. Plant. Cell. Rep. 23: 759-763.

Yuan, J. S., D. Wang and C. N. Jr. Steward. 2008. Statistical methods for efficiency adjusted real-time PCR data. Biotechnol. J. 3: $112-123$

Yun, J. J., L. E. Heisler, I. I. L. Hwang, O. Wilkins, S. K. Lau, M. Hyrcza, B. Jayabalasingham, J. Jing, J. McLaurin, M. S. Tsao and S. D. Der. 2006. Genomic DNA functions as a universal external standard in quantitative real-time PCR. Nucleic Acid Res. 34(12): e85. DOI: 10.1093/nar/gkl400.

Žiarovská, J., K. Ražná, S. Senková, V. Štefúnová and M. Bežo. 2012. Variability of Linum usitatissimum L. based on molecular markers. ARPN J. Agric. Biol. Sci. 7: 50-58. 